\title{
The Relation of Environment and Learning Interest
}

\author{
Pargito \\ \{pargito.1959@fkip.unila.ac.id\}
}

Faculty of Teacher Training and Education, University of Lampung, Indonesia

\begin{abstract}
There are several big traditions of psychological education to limitation of learning. One of them is about learning situation, namely the atmosphere and the circumstan of physical and non physical environment related to learning. The stimulus could be changed into altered and temporary stimulus, such as experimental, temperature, sounds inside and outside the room and all conditions in the personal subject like headache and tired. The emotional is always influenced by environment condition. So, the focus of this research is the relationship of environment and learning interest. This study uses a survey methods, the data will be analyzed with descriptive statistics. The results of the analysis there was a significant relationship between learning environment and student learning interest. There are some points to consider in forming learning environments. Such as, accessibility, traffics, vegetation and sounds waves, cleanliness, beauty and crowding. The indicated that it has not succeeded yet to trigger learning interest.
\end{abstract}

Keywords: learning environment, learning interest

\section{Introduction}

Learning is a vital key in education. As the process, learning always gets spacious place in various disciplines, such as psychological education. Because of the importance, most of research and experiment on psychological education is hoped to achieve deeper understanding of the process of human change.

There are several big traditions of psychological education to limitation of learning. One of them is about learning situation, namely the atmosphere and the circumstan of physical and non physical environment related to learning activities [1].

The stimulus could be changed into altered and temporary stimulus, such as experimental, temperature, sounds inside and outside the room and all conditions in the personal subject like headache and tired [2]. They are mostly from what is called as "learning environment". Therefore, it can be understood that environment plays the role as psychological function [3]. One of the psychological aspects in learning that influences quantity and quality of learning is interest. In short, interest is tend to and enthusiasm or desire to something.

It is known that interest has cognitive and affective [4]. The cognitive is related to concept which is developed by someone toward the ability and intelligently. Affective is the emotional that builds the cognitive. The emotional is always influenced by environment condition. Therefore, learning needs concen- tration. If the stimulation from environment is matched, it will burden that causes someone lost control to the current situation [5].

Therefore, each area in a big city has special developed space for education. So, learning environment formed in that space is hoped to support the education optimally. Some research findings on environment, there are some points to consider in forming learning environments. Some environmental elements to consider are: 


\section{Accessibility}

Accessibility is a measurement of difficulty and easiness of how land interact one another, and also how to beaten it by using transportation network system [6]. Generally, someone's interest is related to someone effort. For example someone who cleans carpet with a broom will certainly needs more energy than use vacuum cleaner [7]. Therefore, students' acessibility of students to reach their place of learning are considered.

\section{Traffic clearance}

If the traffic clearance is considered, it will cause traffic jam. Psychological someone who is faced this condition will feel being chased by time, anxiety, sadness, confusion, irritated, misunderstanding, helpless, unable to anything, nervousness, failure, discouragement. In addition, someone will feel difficulty to concentrate, to think clearly to make decision. Even, he lost his creativity, passion, appearance and interest to others [8].

\section{Vegetation}

Vegetation that located in the city not only control the air pollution also function of controlling environmental temperature or reducing heat. The relationship between environment temperature and human psychological function is vital. A research conducted showed that someone who is inside hot environment is not so interested to others compared with in common temperature. Vegetation also functions to reduce air pollution. A research conducted in China revealed that air pollution also reduce someone's concentration [9].

\section{Sound waves}

Noise is one of source of stress that come from unwanted sound such noise, vehicles sounds or loud music sounds. Some studies proved that noise influences negatively toward personal behavior, causes agregating, reduces one's concentration and nervousness and anxiety. In addition, noise also triggers aggressive behavior to those own aggressive character [10].

\section{Clean lines}

The easiness of students to think and to create are caused by clean learning environment, so it will support the orders and comforted, unlike dirty learning environment. It certainly will trigger laziness and boring that will not create spirit of students. A clean and healthy learning environment can improve the brain to work better [11].

\section{Beauty}

What have been experienced by human through their five senses influence themselves physically and psychologically or unconcious and consciously. Shapes, textures, dimention or scale also color become consideration of a design. There many ways of human to sense the space around, one of them is by seeing, the people will give their physical and psychological responses in their minds. For instance is color. The approach of color from the art side is really closed to psychology. Perception of color involves human psychological and physiological responses [12]. In a study showed that green can decrease the stress. 


\section{Crowding}

Psychological Crowding causes the ability reduction to absorb information, decreases the ability to work if somebody in working condition and affects his break time. Crowding do not only decrease the affinity to others but also individual to control to interact one another. Currently, many crimes and chaos in poor area has bigger crowding [10]. At Zainal Abidin Pagar Alam street which is located in Bandar Lampung City has main function as educational space for college as mentioned in Bandar Lampung master and spatial plan. Currently, there are 7 colleges in that space. The last study showed that there were some congestion in main educational area [13]. It indicates that crowding in the area is also quite high. Normally, the aesthetic values in the environment faded and caused decreasing the psychology function of environment. In short, it raise some question. Is there relationship of environment and learning interest?

\section{Research Method}

The methods use for this research is survey and quantitative approach. Survey is to obtain general portrayal of population character such as who are they, what are they thinking, what are they feeling or the tendency of doing something. This information is used to see what trend on the opinion.

The population of this study is all college students in :

Tabel 1.1 The Population

\begin{tabular}{|r|l|c|}
\hline No. & \multicolumn{1}{|c|}{ Collage } & Imber of Students \\
\hline 1. & Akper Panca Bhakti & 367 \\
\hline 2. & ATRO Patriot Bangsa & 240 \\
\hline 3. & IIB Darmajaya & 5.744 \\
\hline 4. & Universitas Mitra Indonesia & 2.240 \\
\hline 5. & Universitas Bandar Lampung & 6.100 \\
\hline 6. & Universitas Muhammadiyah Lampung & 1.687 \\
\hline 7. & UniversitasTeknokrat Indonesia & 6.576 \\
\hline \multicolumn{2}{|c|}{ Total } & 22.953 \\
\hline
\end{tabular}

The numbers of sample taken by using Isaac and Michael are 267. The instruments of the research are observations, questioner and documentation. All data taken is assessed by using statistics from both variables, and then data is described or interpreted. 


\section{Result and Discussion}

Human and environment always interact and influence one another. Environment also influences how people behave such as how people limit their area.

This research is strengthened that most of students do not have negative perception about acessible to reach their collage. However, one thing to consider is congestion. From this study, it is obtained that most students are often experience congestion. It caused bad accessibility to be vain because congest.

\subsection{Learning Environments}

The accessibility of Zainal Abidin Street is good, because it is secondary arterial road. This research is strengthened that most of students do not have negative perception about acessible to reach their collage. However, one thing to consider is congestion. From this study, it is obtained that most students are often experience congestion. It caused bad accessibility to be vain because congestion.

Study proved that traffic is not only caused by educational activities but also settlement, trading, services and offices that result congestions. It indicates that the level of crowding in Zainal Abidin Street is quite high. This condition is also strengthened by data of this study that most students feel their college building with the environments are congested.

Vegetation that located in the city not only control the air pollution also function of controlling environmental temperature or reducing heat concentrated. The relationship between environment temperature and human psychological function is vital. A research conducted showed that someone who is inside hot environment is not so interested to others compared with in common temperature [10]. Vegetation also functions to reduce air pollution. A research conducted in China revealed that air pollution also reduce someone's concentration [9].

Noise is one of source of stress that come from unwanted sound such noise, vehicles sounds or loud music sounds. Some studies proved that noise influences negatively toward personal behavior, causes aggravated, reduces one's concentrated, nervousness and anxiety. In addition, noise also triggers aggressive behavior to those own aggressive character [10].

Clean lines ,The easiness of students to think and to create are caused by clean learning environment, so it will support the orders and comforted, unlike dirty learning environment. It certainly will trigger laziness and boring that will not create spirit of students. A clean and healthy learning environment can improve the brain to work better [11].

Beauty, What have been experienced by human through their five senses influence themselves physically and psychologically or unciously and consciously. Shapes, textures, dimention or scale also color become consideration of a design. There many ways of human to sense the space around, one of them is by seeing, the people will give their physical and psychological responses in their minds.

Psychological Crowding causes the ability reduction to absorve information, decreases the ability to work if somebody in working condition and affects his break time. Crowding do not only decrease the affinity to others but also individual to control to interact one another. Currently, many crimes and chaos in poor area has bigger crowding [10].

Related to healthy, the clean lines management done in Zainal Abidin Street play important role, almost no amount of garbage found, most of students also do not feel that this street is dirty. However, another factor on healthy is like pollution, vegetation around the street is not able to cover the quantity of pollution. Therefore because most students still feel 
the air pollution in their learning environment.

\subsection{Learning Interest}

Learning is the effect of interaction between stimulus and response. Leaning environment is part of someone's stimulus to learn. Therefore, learning needs concentration and stable emotional condition. The changing of activities inside the brain is temporary variable between stimulus and responses (Donald Olding Hebb, 1972). The good learning process will create relation between stimulus and responses. If stimulus is bigger than capacity of information, it will neglect some stimulus to make each individual focus on one stimulus.

Regarding to the attention, the data resulted from this study, many activities in Abidin street besides of education is not seen that there is significant difference on students who have more focus and who have less focus. However, the congestion affects students learning interest. Then the participation of students to learn, like finding a comfortable place to study beside classroom is nor significant. In another words, most students still have and get the place to participate in learning around collage. But, related to students' feeling, they still need to learn to adapt with their learning environment in ZainalAbidin street.

\subsection{The Relationship Between Learning Environment and Learning Interest}

Based on the character correlation, the relationship between $\mathrm{X}$ variable (Leaning environment) with $\mathrm{Y}$ variable (learning interest) is positive. It is indicated by the regression equation because the coefficient is positive, the fuctional as well. In other words, it is predicted that if the score of $\mathrm{X}$ variable increases, the tendency of average $\mathrm{Y}$ variable also increases. Therefore, the correlation is called positive correlation. This is also in line with Donald OldingHebb, Cohen and Milgram that the increasing or the decreasing someone's passion is influenced by environment. If it is negative, it will affect negatively toward someone's interest.

While it is seen that environment contribution in influencing learning interest is $36,1 \%$. It shows that many factors also influence the interest. It is as what stated by Crow, L. D. \& Crow, A that interest is not only influenced by environment, and others factors like social and internal. In other word, most of distribution that affects interest exists.

The result of this study also strengthened the theory stated by experts, such Hamalik stated that environment has some functions one of them is psychological function. Muhibbin Syah revealed that one of psychological aspects that effect the quantity and quality of learning is interest. His idea is strengthened by Crow, L. D., \& Crow, A that environment is one of the factors that influence interest. Donald Olding Hebb, Cohen dan Milgram also argue that how environment related to interest and passion.

\section{Conclusion}

Looking at the responses, each indicator from sub variable of learning environment and learning interest showed that learning environment position in Zainal Abidin Pagar Alam Street is indicated that trigger learning interest which means environment is only a requirement to conduct education. It means that environment has relation with learning interest, therefore it should be endeavored to make environment trigger students' productivity. 


\section{Suggestion}

Local government should re-consider the licence to open entertainment such as Karaoke and others, because does not only have educative purpose but also increase congestion that reduce students' productivity. Then, related to vegetation on the side walks and surrounding need to be watered and fertilized daily to accelerate the growth to reduce air pollution. All students that experienced congestion and lateness should avoid working time or come earlier.

\section{References}

[1] M. Syah, "Psikologi Belajar, Jakarta: PT," Raja Graf. Persada, 2006.

[2] B. R. Hergenhahn and M. H. Olson, "Theories of Learning (teori belajar)," Tri Wibowo BS (Alih bahasa). Jakarta Kencana Prenada Media Gr., 2008.

[3] O. Hamalik, Proses belajar mengajar. Bumi Aksara, 2004.

[4] S. Retnaningsih, "Kajian Evaluatif Ruang Terbuka Hijau (RTH) Taman Sampangan dan Taman Tirtoagung Di Kota Semarang," Unika Soegijapranata, 2017.

[5] A. F. Helmi, "Beberapa Teori Psikologi Lingkungan," Bul. Psikol., vol. 7, no. 2, 1999.

[6] Irfan, Analisis Aksesibilitas Kendaraan Pribadi Menuju Kampus Universitas Negeri Makasar Gunung Sari. Makassar: Universitas Negeri Makassar, 2014.

[7] A. Crow, L. D., \& Crow, An Outline as General Psychology. New York: Littlefield Adam and Co, 1982.

[8] M. Tondok, "Stress Kemacetan Lalu-lintas," Harian Surabaya, Surabaya, 18-Aug2009.

[9] X. Zhang, "The Impact of Exposure to Air Pollution on Cognitive Performance," Proc. Natl. Acad. Sci., vol. CXV, No. 3, 2018.

[10] F. Lubabin, "Pengaruh Lingkungan Terhadap Perilaku Manusia," J. Psiko Islam., vol. II, 2005.

[11] N. Hidayati, "Persepsi Siswa terhadap Kebersihan Lingkungan di Sdn 51 Banda Acehpersepsi Siswa terhadap Kebersihan Lingkungan di Sdn 51 Banda Aceh," J. Ilm. Mhs. Pendidik. Guru Sekol. Dasar, vol. 1, no. 1, 2016.

[12] A. Rahayu, "Peran Warna dalam Arsitektur sebagai Salah Satu Kebutuhan Manusia," Skripsi. Fak. Tek. Progr. Stud. Arsitektur. Univ. Indones., 2012.

[13] M. Virsa, "Pengaruh Perubahan Penggunaan Lahan Terhadap Bangkitan Lalu Lintas Pada Koridor Jalan Zainal Abidin Pagar Alam di Kota Bandar Lampung," Universitas Lampung, 2016. 